\title{
Effect of Storage on Bioactive Compounds of Tomato And Its Products
} Tesby Mohamed Rashad Lotfy ${ }^{(1)}$. Neveen Fahmy Mohamed Agamy ${ }^{(2)}$. Amira
Ahmed Ahmed Shetewy ${ }^{(1)}$. Aishah Anees Abd El-Wahab Abu shehata ${ }^{(1)}$.

1. Faculty of Specific Education, Alexandria University. Egypt.

2. Hight institute of Public Health, Alexandria University. Egypt.

\begin{abstract}
Tomatoes are considered as functional food due its considerable content of anti-oxidant and dietary fibers. Accordingly, the present study was conducted to study the effect of storing tomatoes and their products (juice, ketchup and tomato paste ) in the refrigerator for a week and two weeks in the freezer for a month, two months and three months on the bioactive compounds. Results show a marked increase in lycopene content when storing products for two months in freezer was detected for tomato paste $(11.06 \mathrm{mg} / 100 \mathrm{~g})$ while increase by $221.51 \%$. According to antioxidants content in fresh products showing it was (39.45\% Inhibition), On the other hand, effect of storage tomato paste for two weeks in the refrigerator was the best $(8.24 \%)$. While storing for one month in the freezer was the best $(9.56 \%)$. The highest vitamin $\mathrm{C}$ content after storing one week in the refrigerator was detected in tomato $(38.49 \mathrm{mg} / 100 \mathrm{~g})$. Effect of storage Vitamin C percent of tomato paste increased by $22.21 \%$ after two months of freezer storage. Thus, tomato paste isadvised due to it contains good amount of antioxidants, Lycopene and vitamin C.
\end{abstract}

\section{Introduction}

Tomato is a member of the Solanaceae family (Petro - Turza, 1978). It can be consumed either fresh or processed in the form of tomato products (Toor and Savage, 2005). Tomato (Solanum Lycopersicum L.) is one of the world's most important vegetables, with an estimated total production of about 159.347 million tons in 2011 (FAOSTA, 2011). It is the second most widely consumed vegetable after potato (Lugasi et al., 2003). Tomato processing industry has made tremendous advances, developing many forms of tomatobased foods, such as sauces, ketchup, puree, pastes, soups, juices and juice 
blends, and canned tomatoes either whole or in diced, sliced, quartered or stewed form.

Tomatoes are low in calories and a good source of vitamin A and C (Parnell et al., 2004 ), minerals (potassium, phosphorus, sulphur, magnesium, calcium, iron, copper, and sodium) (Viskelis et al., 2005). The regular consumption of tomatoes and tomato products has been correlated to a reduction the risk of injssed with various types of cancer and cardiovascular diseases. This positive effect is attributed to the antioxidants present in tomatoes (Borguini and Torres, 2009). It considered to be a source of carotenoids, in particular lycopene and phenolic compounds (Pinela et al., 2012).

The nutritional value of tomato production is a topic attracting much attention particularly regarding the effects resulting from processing and storage treatments (Capanoglu et al., 2010). Conversion of tomato into paste provides a way out for extended shelf life storage periods (Jamil, 1990). The effect of storage temperature on physiochemical quality and quantity changes in tomatoes, varies with cultivar (Abou-Aziz et al., 1976), exposition time (Hobson, 1981) and harvesting conditions (Autio and Bramlage, 1986). During thermal treatment, several additional changes can occur which affect the appearance, composition, nutritional value, and sensory parameters in terms of color, texture, and flavor of the product (Capanoglu et al., 2008). Therefore, the purpose of this study is to evaluate the effect of storage on bioactive compounds of tomato and its products.

\section{Material and methods}

\subsection{Material}

\subsection{1. study setting:}

* The Laboratory of Nutrition, Faculty of Specific Education, Alexandria University, Egypt.

* The Central Laboratory, High Institute of Public Health, Alexandria University, Egypt.

* The Central Laboratory, Unit of Analysis and scientific services , Faculty of Agriculture, Alexandria University, Egypt.

\subsubsection{Sampling}

Twenty kilo grams of fresh tomatoes (Lycopersicon esculentum L) were bought from Rashid Market. Tomatoes, were processed to make tomato juice, 
ketckup and tomato juice. Sensory evaluation of the products was done in the Laboratory of Nutrition, Faculty of Specific Education, Alexandria University. Sensory evaluation was done for fresh store products for analysis by $\operatorname{cold}\left(4^{\circ} \mathrm{C}\right)$ and freezing at $\left(2^{\circ} \mathrm{C}\right)$ storage .

Ingredients used for food preparation of products included: Fresh red tomatoes, parsley, salt, garlic, vinegar, seasoning (spices, black pepper), butter, sugar, onion, Glass jars and polyethylene bags were bought from Fathalla supermarket, Ibrahimieh, Alexandria.

\subsection{Methods.}

\subsubsection{Determination of Antioxidants}

The sample was weighted by $500 \mathrm{~g}$. The sample was gridded to pass completely throw sieve No-20. The ground portion was mixed thoroughly, samples for analysis taken after mixing, using sample splitter. Additional portions prepared from lot sample in the same way if needed.

\section{Extraction of sample}

- $50 \mathrm{~g}$ of ground sample was mixed with $25 \mathrm{~g}$ of calcite and $250 \mathrm{ml}$ of chloroform followed by $25 \mathrm{ml}$ of distilled water in a glass bottle $(500 \mathrm{ml})$ then it was added.

- The ground sample was mixed for $30 \mathrm{~min}$ on a shaker at $200 \mathrm{rpm}$ speed.

- An aliquant of the chloroform extract was filtered through a Whatman No. 2.v. $24 \mathrm{~cm}$. filter paper.

- $50 \mathrm{ml}$ filtrate was passed $(=10.5 \mathrm{~g}$ sample $)$ throw the activated florisil column.

Sample was injected in HPLC(AOAC, 2003)

\section{Determination of lycopene content}

The lycopene content was determined following the method of AOAC (1998)

\section{Extraction}

Wiegh 5-10 g of the juice, puree, or ketchup. Extract repeatedly with acetone in a pestle and mortar or a blender until the residue is less colour. Transfer the acetone extract to a separating funnel containing 10 to $15 \mathrm{ml}$ of petroleum ether and mix gently. Take up the carotenoid pigments in to the petroleum ether by diluting the acetone (lower phase) with water or water containing $5 \% \mathrm{Na}_{2} \mathrm{SO}_{4}$. Transfer the lower phase to another separating funnel and the petroleum ether extract containing the carotenoid pigments to an amber 
coloured bottle. Repeat extraction of the acetone phase similarly with petroleum ether until it is less colour. Discard the acetone phase. To the petroleum ether extract, add a small quantity

of anhydrous $\mathrm{Na}_{2} \mathrm{SO}_{4}$, transfer to a 50-ml volumetric flask and dilute to mark with petroleum ether.

Dilute an aliquot $(5 \mathrm{ml}$, if the test sample is tomato juice or ketchup and $2 \mathrm{ml}$, if puree) to $50-\mathrm{ml}$ with petroleum ether and measure the colour in a $1 \mathrm{~cm}$ cell at $503 \mathrm{~nm}$ in a spectrophotometer using petroleum ether as a blank.

\subsubsection{Vitamin $\mathrm{C}$ content}

Vitamin $\mathrm{C}$ was extracted according to the modified method of Abdulnabi et al., (1997). The sample (10 g) was homogenised with an extracting solution containing meta-phosphoric acid $(0.3 \mathrm{M})$ and acetic acid $(1.4 \mathrm{M})$. The mixture was placed in a conical flask (wrapped with aluminum foil) and agitated at 100 rpm with the aid of an orbital shaker for $15 \mathrm{~min}$ at room temperature. The mixture was then filtered through a Whatman No. 4 filter paper to obtain a clear extract. The ratio of the sample to extraction solution was 1 to 1 .

All samples were extracted in triplicates.

\section{Results and Discussion}

\subsection{Lycopene products:}

Data in Table 1 and Figure 1 show that

a) The highest lycopene content for fresh products was detected in ketchup $(5.42 \mathrm{mg} / 100 \mathrm{~g})$, while the least content was detected for tomato $(2.56 \mathrm{mg} / 100 \mathrm{~g})$.

b) The highest lycopene content when storing products for the month was detected for tomato paste $(6.52 \mathrm{mg} / 100 \mathrm{~g})$, while the least content was detected for tomato $(1.51 \mathrm{mg} / 100 \mathrm{~g})$.

c) The highest lycopene content when storing products for two months was detected for tomato paste $(11.06 \mathrm{mg} / 100 \mathrm{~g})$, while the least content was detected for tomato $(0.55 \mathrm{mg} / 100 \mathrm{~g})$.

The tomato paste was the highest in lycopene content when storage. On the other hand, the stored tomatoes had the least lycopene content when storing. These results agree with the

published data (Alda et al ., 2016) (Tomato $2,58 \mathrm{mg} / 100 \mathrm{~g}$ ). While the results according to ketchup and tomato paste disagree with these findings (for ketchup $7,12 \mathrm{mg} / 100 \mathrm{~g}$, for tomato paste $5,65 \mathrm{mg} / 100 \mathrm{~g}$ ). That's may be due to the changing in the tomatoes variety or the method for processing. 
Results show that lycopene concentration increases by processing. Lycopene concentration also increased significantly at one and two months of freezer storage $\left(-20 \mathrm{C}^{\circ}\right)$. Bernhardt and Schlich, (2006) mentioned that cooking increases the bioavailability of lycopene by disruption of the plant cell wall and releasing it form protein complexes.

Studies by Hadley et al.,(2002), have shown that cooking or heating tomatoes release the lycopene. For example, fresh tomatoes contain between 30 and $70 \mathrm{mg}$ of lycopene per kilogram, whereas tomato paste contains 300 mg per kilogram (Lyc-o-mato, 203). Other

processed tomato products, such as ketchup and pizza sauce, also contain large amounts of lycopene. Rao and Agarwal (2000) mentioned that tomato and processed tomato products are good source of lycopene. Its quantity is affected by tomato variety and ripening stage

Table 1. Analysis of lycopene in tomato and its products

\begin{tabular}{lccc}
\cline { 2 - 4 } Products & Fresh & $\begin{array}{c}\text { Lycopene mg/100g } \\
\text { One month } \\
\text { storage }\end{array}$ & $\begin{array}{c}\text { Two months } \\
\text { storage }\end{array}$ \\
\hline Tomato & 2.56 & 1.51 & 0.55 \\
Tomato juice & 4.39 & 6.09 & 2.40 \\
Ketchup & 4.49 & 5.42 & 2.55 \\
Tomato paste & 3.44 & 6.52 & 11.06 \\
\hline
\end{tabular}

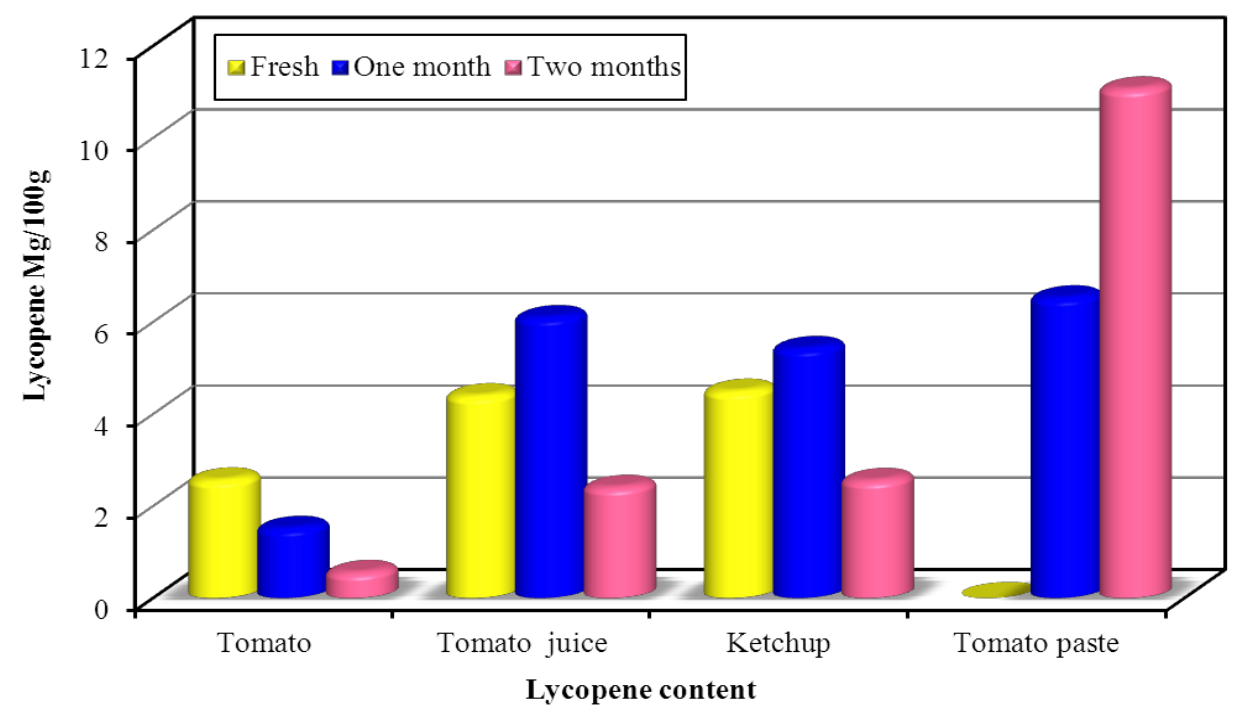

Figure 1. Analysis of lycopene in tomato and its products. 


\subsection{Antioxidants}

Tomatoes and tomato products are rich in food components that are antioxidant (George et al. 2004.; Sahlin et al. 2004.; Ilahy et al. 2011 and Pinela et al. 2012).

Table 2 and Figure (2) show that:-

a- The highest antioxidants content in fresh products was detected in tomato (39.45\% Inhibition), while the least content was detected in ketchup (28.45\% Inhibition).

b- The highest antioxidants content after storing one week in the refrigerator was detected in tomato (38.49\% Inhibition ), while the least content was detected in tomato paste (20.24\% Inhibition).

c- The highest antioxidants content after storing two weeks in the refrigerator was detected in tomato (35.77\% Inhibition), while the least content was detected in ketchup ( $25.60 \%$ Inhibition).

d- The highest antioxidants content after storing one month in the freezer was detected in tomato (37.87\% Inhibition), while the least content was detected in ketchup (27.43\% Inhibition).

e- The highest antioxidants content after storing two months in the freezer was detected in tomato (32.45\% Inhibition), while the least content was detected in ketchup (22.34\% Inhibition).

f- The highest antioxidants content after storing three months in the freezer was detected in tomato (26.57\% Inhibition ), while the least content was detected in ketchup (18.34\%Inhibition).

Table 2. Antioxidants content for tomato and its products after storage

\begin{tabular}{lcccccc}
\hline Products & \multicolumn{7}{c}{ Antioxidants Inhibition\% } \\
\cline { 2 - 7 } & $\begin{array}{l}\text { Fresh } \\
\text { products }\end{array}$ & $\begin{array}{c}\text { One week } \\
\text { storage } \\
\text { (refrigerator) }\end{array}$ & $\begin{array}{c}\text { Two weeks } \\
\text { storage } \\
\text { (refrigerator) }\end{array}$ & $\begin{array}{c}\text { One month } \\
\text { storage } \\
\text { (freezer) }\end{array}$ & $\begin{array}{c}\text { Two months } \\
\text { storage } \\
\text { (freezer) }\end{array}$ & $\begin{array}{c}\text { Three } \\
\text { months } \\
\text { storage } \\
\text { (freezer) }\end{array}$ \\
\hline Tomato & 39.45 & 38.49 & 35.77 & 37.87 & 32.45 & 26.57 \\
$\begin{array}{l}\text { Tomato } \\
\text { Juice }\end{array}$ & 37.17 & 35.34 & 30.45 & 28.11 & 26.11 & 22.70 \\
$\begin{array}{l}\text { Ketchup } \\
\text { Tomato }\end{array}$ & 28.45 & 30.16 & 25.60 & 27.43 & 22.34 & 18.34 \\
paste & 30.11 & 20.24 & 32.59 & 32.99 & 26.11 & 20.56 \\
\hline
\end{tabular}




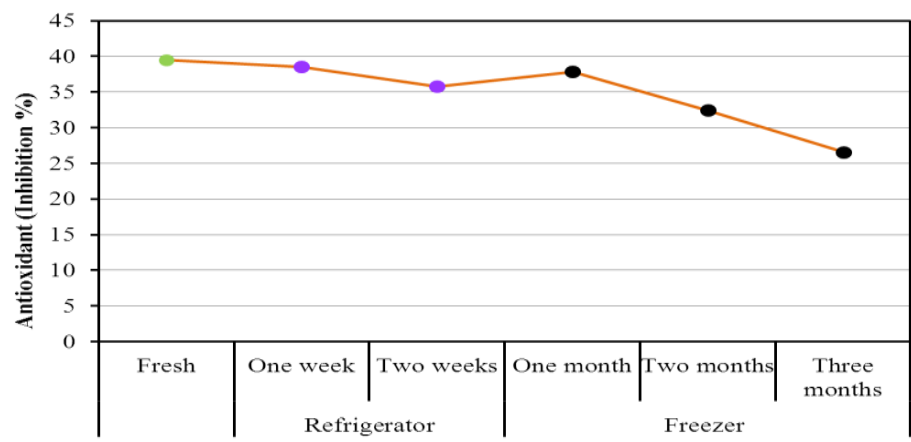

Antioxidant for stored tomatoes (Inhibition\%)

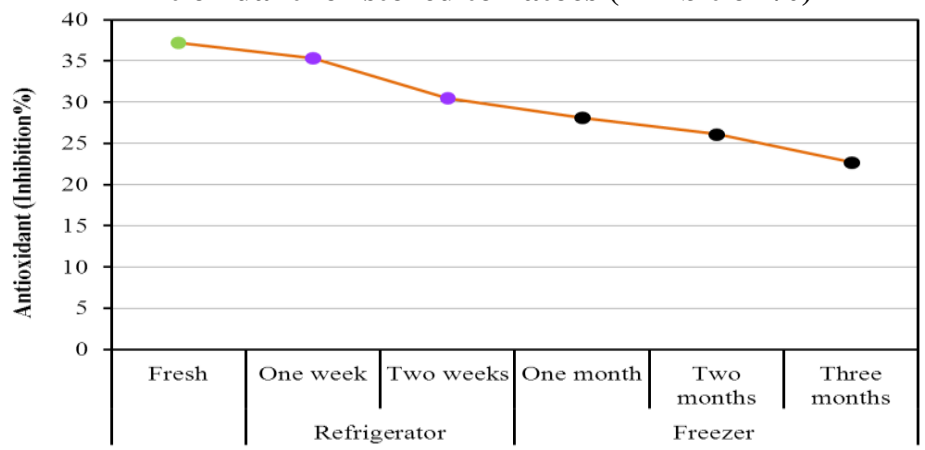

Antioxidant for stored tomato juice (Inhibition\%)

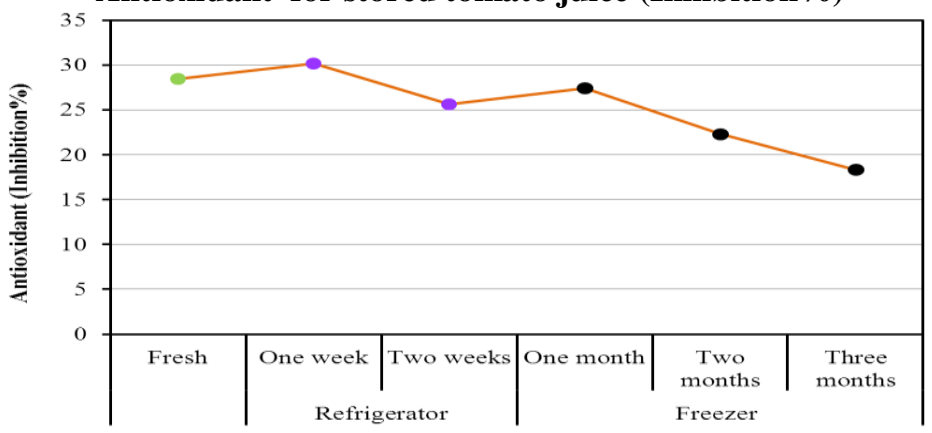

Antioxidant for stored ketchup (Inhibition \%)

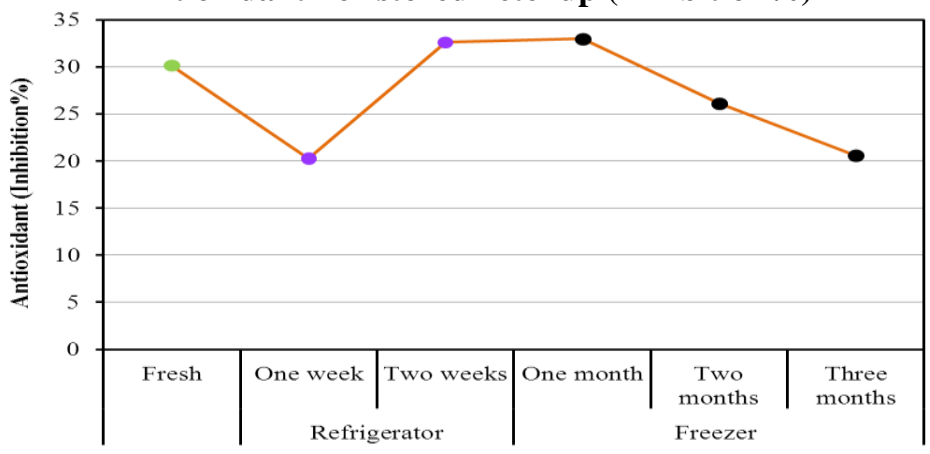

Antioxidant for stored tomato paste (Inhibition \%)

Figure 2. Antioxidant content for stored tomatoes and its products 


\subsection{Vitamin $\mathbf{C}$ content on tomato and its products after storage}

Table 3 and Figure (3) show that

a- The highest vitamin $\mathrm{C}$ content in fresh products was detected in tomato $(34.73 \mathrm{mg} / 100 \mathrm{~g})$, while the least content was detected in tomato paste $(21.56 \mathrm{mg} / 100 \mathrm{~g})$. This nearly similar to that of USDA (2009) when the percentage was $21.9 \mathrm{mg} / 100 \mathrm{~g}$ for tomato paste.

b- The highest vitamin $\mathrm{C}$ content after storin one week in the refrigerator was detected in tomato $(38.49 \mathrm{mg} / 100 \mathrm{~g})$, while the least content was detected in tomato paste $(20.24 \mathrm{mg} / 100 \mathrm{~g})$.

c- The highest vitamin $\mathrm{C}$ content after storing two weeks in the refrigerator was detected in tomato juice $(32.79 \mathrm{mg} / 100 \mathrm{~g})$, while the least content was detected in tomato paste $(20.28 \mathrm{mg} / 100 \mathrm{~g})$.

d- The highest vitamin $\mathrm{C}$ content after storing one month in the freezer was detected in tomato juice $(35.15 \mathrm{mg} / 100 \mathrm{~g})$, while the least content was detected in ketchup $(20.55 \mathrm{mg} / 100 \mathrm{~g})$.

e- The highest vitamin $\mathrm{C}$ content after storing two months in the freezer was detected in tomato juice $(32.72 \mathrm{mg} / 100 \mathrm{~g})$, while the least content was detected in ketchup (24.76 mg/100g).

$\mathrm{f}-$ The highest vitamin $\mathrm{C}$ content after storing three months in the freezer was detected in tomato juice $(31.35 \mathrm{mg} / 100 \mathrm{~g})$, while the least content was detected in ketchup $(20.24 \mathrm{mg} / 100 \mathrm{~g})$.

Table 3. Vitamin C content in tomato and its products after storage

\begin{tabular}{lcccccc}
\hline & \multicolumn{7}{c}{ Vitamin C mg/100g } \\
\cline { 2 - 7 } Products & $\begin{array}{l}\text { Fresh } \\
\text { products }\end{array}$ & $\begin{array}{l}\text { One week } \\
\text { storage } \\
\text { (refrigerator) }\end{array}$ & $\begin{array}{l}\text { Two weeks } \\
\text { storage } \\
\text { (refrigerator) }\end{array}$ & $\begin{array}{l}\text { One month } \\
\text { storage } \\
\text { (freezer) }\end{array}$ & $\begin{array}{l}\text { Two months } \\
\text { storage } \\
\text { (freezer) }\end{array}$ & $\begin{array}{l}\text { Three months } \\
\text { storage } \\
\text { (freezer) }\end{array}$ \\
\hline Tomato & 34.73 & 38.49 & 31.69 & 34.15 & 30.33 & 30.23 \\
$\begin{array}{l}\text { Tomato } \\
\text { Juice }\end{array}$ & 32.60 & 33.85 & 32.79 & 35.15 & 32.72 & 31.35 \\
$\begin{array}{l}\text { Ketchup } \\
\text { Tomato }\end{array}$ & 25.02 & 24.01 & 22.32 & 20.55 & 24.76 & 20.24 \\
paste & 21.56 & 20.24 & 20.28 & 25.91 & 26.35 & 22.55 \\
\hline
\end{tabular}




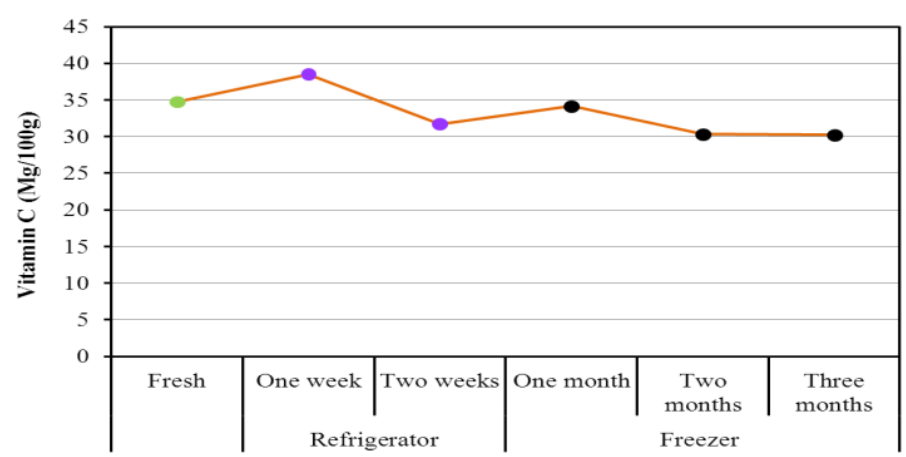

Vitamin C for stored tomatoes (mg/100g)
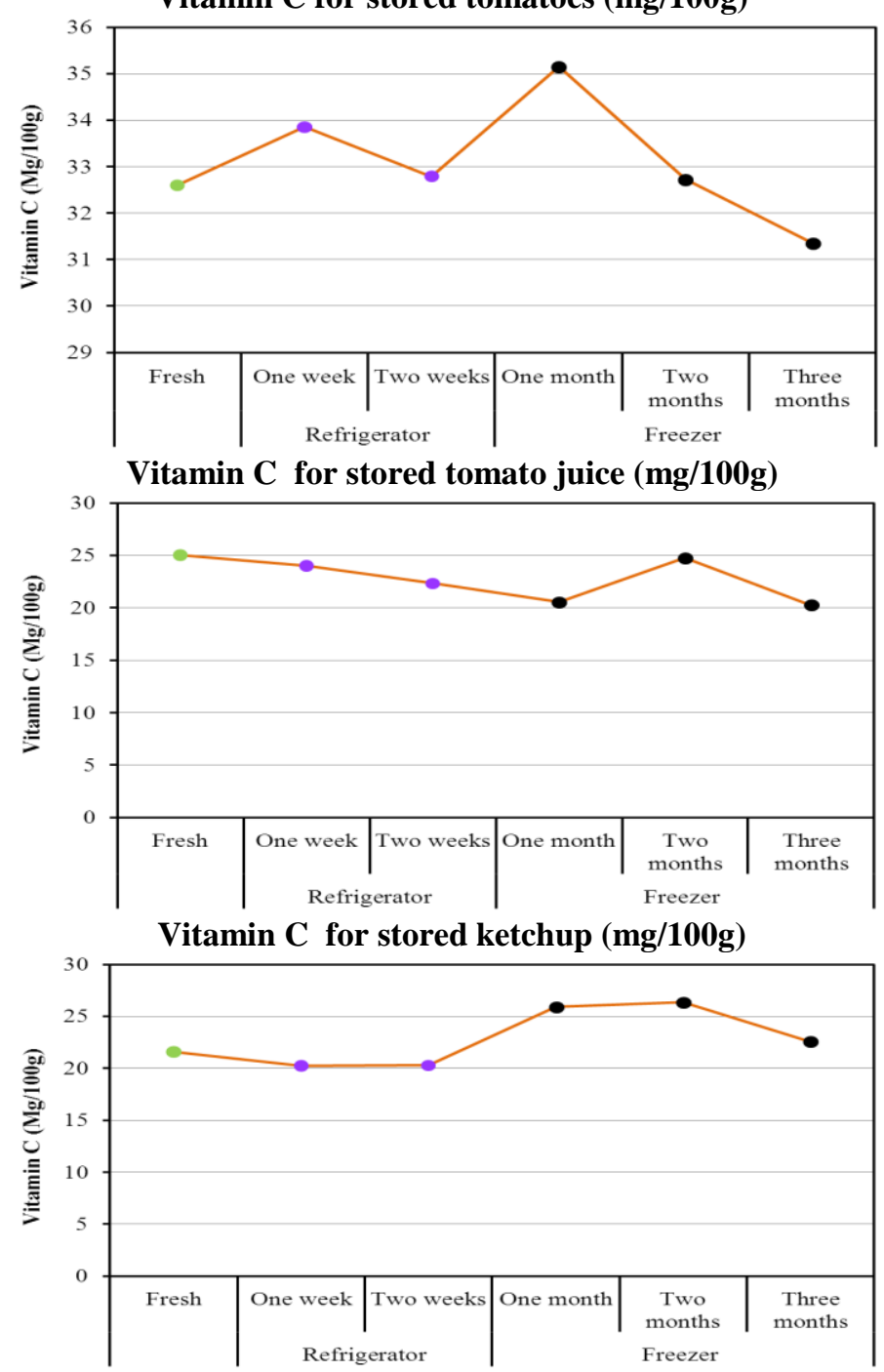

Vitamin C for stored tomato paste $(\mathbf{m g} / \mathbf{1 0 0 g})$

Figure 3. Vitamin $\mathrm{C}$ content for stored tomatoes and its products 


\subsection{Effect of storage on lycopene content of tomato and its products}

Table 4 shows that

\subsubsection{Tomato}

Lycopene percent of fresh tomatoes decreased by $41.01 \%$ after one month of freezer storage while decreased by $78.51 \%$ after two months.

\subsubsection{Tomato juice}

Lycopene percent of tomatoes juice increased by $38.72 \%$ after one month of freezer storage while decreased by $45.33 \%$ after two months.

\subsubsection{Ketchup}

Lycopene percent of ketchup increased by $20.71 \%$ after one month of freezer storage while decreased by $76.08 \%$ after two months.

\subsubsection{Tomato paste}

Lycopene percent of tomato paste increased by $89.53 \% \%$ after one month of freezer storage while increased by $221.51 \%$ after two months.

Research results show that the storage of tomato juice, ketchup, and tomato paste for a month in the freezer has increased lycopene percent and it was better than two- month storage, while the percent of lycopene in tomato paste has increased greatly after two months. The percent of lycopene in tomatoes, tomato juice, and Ketchup has decreased after two- month storage in the freezer. The concentration of lycopene has increased by processing than in fresh tomato. Bernhardt and Schlich (2006) mentioned that cooking increases the bioavailability of lycopene by disruption of the plant cell wall and releasing it form protein complexes. Studies by Hadley et al., (2002), have shown that cooking or heating tomatoes release the lycopene. For example, fresh tomatoes contain between 30 and $70 \mathrm{mg}$ of lycopene per kilogram, whereas tomato paste contains $300 \mathrm{mg}$ per kilogram (Lyc-o-mato, 203). Other processed tomato products, such as ketchup and tomato paste, also contain large amounts of lycopene.

Lycopene is a natural compound that is found in large quantities in red color tomatoes (Novelina et al., 2016). Lycopene is a carotenoid that is present in tomatoes, processed tomato products tomatoes and tomato products containing lycopene (Agarwal and Rao, 2000).

Recently, many studies have shown that heat processing of tomato into various products like tomato paste, ketchup and sauces induce isomerization of lycopene from trans to cis configuration and hence increases its bioavailability (Stahl and Sies, 1992). A negligible increase in plasma lycopene level was observed after consumption of unheated tomato juice 
(Brown, 1989). However, when oil was mixed with heated tomato juice and consumed, then plasma lycopene concentration was found to increase after 24-48hr of ingestion (Stahl and Sies, 1992). Lycopene absorption and its bioavailability depend upon the fat content of the meal, processing of lycopene-containing food and heat-induced isomerization (Rao and Agarwal, 1999).

Table 4. Effect of storage on lycopene content of tomato and its products

\begin{tabular}{ccc}
\hline \multirow{2}{*}{ Products } & \multicolumn{2}{c}{ Lycopene \% } \\
\cline { 2 - 3 } & $\begin{array}{c}\text { After one } \\
\text { month }\end{array}$ & $\begin{array}{c}\text { After two } \\
\text { months }\end{array}$ \\
\hline Tomato & -41.01 & -78.51 \\
Tomato juice & 38.72 & -45.33 \\
Ketchup & 20.71 & -76.08 \\
Tomato paste & 89.53 & 221.51 \\
\hline
\end{tabular}

\subsection{Effect of storage on antioxidants content inhibition}

\subsubsection{Effect of storage on antioxidants content inhibition of tomato and its products in the refrigerator}

Table 5 show that

- Antioxidants inhibition percent of fresh tomatoes decreased by $10.42 \%$ after one week of refrigerator storage while decreased by $9.33 \%$ after two weeks.

- Antioxidants inhibition percent of tomato juice decreased by $18.86 \%$ after one week of refrigerator storage while decreased by $18.08 \%$ after two weeks.

- Antioxidants inhibition percent of ketchup decreased by $8.96 \%$ after one week of refrigerator storage while decreased by $8.96 \%$ after two weeks.

- Antioxidants inhibition percent of tomato paste increased by $7.01 \%$ after one week of refrigerator storage while increased by $8.24 \%$ after two weeks. 


\subsubsection{Effect of storage on antioxidants content inhibition of tomato and its products in the freezer}

Table 6 shows that

- Antioxidants inhibition percent of fresh tomato decreased by $4 \%$ after one month of freezer storage while decreased by $17.74 \%$ after two months, and after three months it decreased by $32.64 \%$.

- Antioxidants inhibition percent of tomato juice decreased by $24.37 \%$ after one month of freezer storage while decreased by $29.75 \%$ after two months, and after three months it decreased by $38.93 \%$.

- Antioxidants inhibition percent of ketchup decreased by $3.59 \%$ after one month of freezer storage while decreased by $21.48 \%$ after two months, and after three months it decreased by $35.34 \%$.

- Antioxidants inhibition percent of tomato juice increased by 9.56\% after one month of freezer storage while decreased by $13.28 \%$ after two months and after three months it decreased by $31.72 \%$.

The present study according to antioxidant content for "stored tomatoes"

It is well known that naturally occurring antioxidants could be significantly lost as a consequence of processing and storage. In particular, thermal treatments are generally believed to be the main cause of the depletion in natural antioxidants (Jonsson, 1991).

The resent study (Table 5and 6) showed that antioxidant decreased by storing in the refrigerator and freezer in tomatoes, tomato juice, and ketchup. While they also showed that storing tomato paste for one week and two weeks in the refrigerator increased similarly. On the other hand, storing for two weeks was the best. While storing for one month in the freezer was the best of all. 
Table 5. Effect of storage on antioxidants content inhibition of tomato and its products in the refrigerator

Antioxidants Inhibition (\%)

\section{Products}

\begin{tabular}{lcc}
\cline { 2 - 3 } & $\begin{array}{c}\text { After one } \\
\text { week }\end{array}$ & $\begin{array}{c}\text { After two } \\
\text { weeks }\end{array}$ \\
\hline Tomato & -10.42 & -9.33 \\
Tomato juice & -18.86 & -18.08 \\
Ketchup & -8.96 & -8.96 \\
Tomato paste & 7.01 & 8.24 \\
\hline
\end{tabular}

Table 6. Effect of storage on antioxidants content inhibition of tomato and its products in the freezer

Antioxidants Inhibition (\%)

Products

After one month After two months After three months

\begin{tabular}{lccc}
\hline Tomato & -4 & -17.74 & -32.64 \\
Tomato juice & -24.37 & -29.75 & -38.93 \\
Ketchup & -3.59 & -21.48 & -35.34 \\
Tomato paste & 9.56 & -13.28 & -31.72 \\
\hline
\end{tabular}

\subsection{Effect of storage on vitamin C}

3.6.1. Effect of storage on vitamin C (\%) content of tomato and its products the refrigerator

Table 7 shows that

- Vitamin C percent of fresh tomatoes increased by $10.82 \%$ after one week of refrigerator storage while decreased by $8.75 \%$ after two weeks. This might be due to that tomatoes were exposed in the refrigerator to chilly injury causing firmness decay and mechanical injury (Farneti et al., 2009). 
- Vitamin C percent of tomato juice increased by $3.83 \%$ after one week of refrigerator storage while increased by $0.58 \%$ after two weeks.

- C percent of ketchup decreased by $4.04 \%$ after one week of refrigerator storage while decreased by $10.80 \%$ after two weeks.

- Vitamin C percent of tomato paste decreased by $6.12 \%$ after one week of refrigerator storage while decreased by $5.94 \%$ after two weeks.

\subsubsection{Effect of storage on vitamin C (\%) content of tomato and its products in the freezer}

Table 8 shows that

- Vitamin C percent of fresh tomato decreased by1.67\% after one month of freezer storage while decreased by $12.69 \%$ after two months, and after three months it decreased by $12.96 \%$. Chitarra 1994 mentioned that significant losses of nutrients, especially vitamin $\mathrm{C}$, may occur during the storage.

- Vitamin C percent of tomato juice increased by $7.82 \%$ after one month of freezer storage while increased by $0.03 \%$ after two months, and after three months it decreased by $3.83 \%$.

- Vitamin C percent of ketchup decreased by $17.87 \%$ after one month of freezer storage while decreased by $1.04 \%$ after two months, and after three months it decreased by $18.30 \%$.

- Vitamin C percent of tomato paste increased by $20.18 \%$ after one month of freezer storage while increased by $22.21 \%$ after two months, and after three months it increased by $4.60 \%$.

\section{The present study according to vitamin $\mathbf{C}$ content for stored tomatoes}

Red tomatoes contain $25 \mathrm{mg}$ ascorbic acid $/ 100 \mathrm{~g}$ of tomatoes by weight. In this way, tomatoes are a valuable source of ascorbic acid that helps to protect our body from various diseases (Leoni and Jongen, 2002). Table (7and 8) show that

- Vitamin $\mathrm{C}$ in tomatoes was better when it was stored for one week in the refrigerator. However, it by storing for a week losses were found. 
- Vitamin $\mathrm{C}$ in tomato juice increased by storing for one week in the refrigerator and it was better than storing two weeks but storing for one month in the freezer was the best.

- Vitamin $\mathrm{C}$ in ketchup decreased in all stages of storing in the refrigerator and freezer.

- Vitamin $\mathrm{C}$ in tomato paste decreased by storing in the refrigerator but it increased by storing in the freezer in all stages, on the other hand, store for two months in the freezer was the best.

- $\quad$ Generally, vitamin $\mathrm{C}$ decreased by storing in most products. The loss in the ascorbic acid content of the tomato samples occured with storage time. The higher temperature at which these samples were prepared is probably responsible for this, the loss of ascorbic acid having been reported to be corresponding to temperature (Garangyo et al., 1992).

Losses of vitamin $\mathrm{C}$ in the tomatoes stored in the refrigerator are due to the effect of oxidative enzymes in the vegetables. As it is well known that blanching of vegetables before freezing is required to stop the action of the oxidative enzymes present in tomatoes.

Losses of unblanched vegetables before freezing are from 2-3 times as great as those from blanched vegetables (Ensminger et al., 1995).

Table 7. Effect of storage on vitamin C content of tomato and its products the refrigerator

\section{Vitamin C (\%)}

Products

\begin{tabular}{lcc}
\cline { 2 - 3 } & $\begin{array}{c}\text { After one } \\
\text { week }\end{array}$ & $\begin{array}{c}\text { After two } \\
\text { weeks }\end{array}$ \\
\hline Tomato & 10.82 & -8.75 \\
Tomato juice & 3.83 & 0.58 \\
Ketchup & -4.04 & -10.80 \\
Tomato paste & -6.12 & -5.94
\end{tabular}


Table 8. Effect of storage on vitamin $\mathrm{C}$ content of tomato and its products in the freezer

\section{Vitamin C (\%)}

Product

\begin{tabular}{lccc}
\cline { 2 - 4 } & $\begin{array}{c}\text { After one } \\
\text { month }\end{array}$ & $\begin{array}{c}\text { After two } \\
\text { months }\end{array}$ & $\begin{array}{c}\text { After three } \\
\text { months }\end{array}$ \\
\hline Tomato & -1.67 & -12.69 & -12.96 \\
Tomato juice & 7.82 & 0.03 & -3.83 \\
Ketchup & -17.87 & -1.04 & -18.30 \\
Tomato paste & 20.18 & 22.21 & 4.60 \\
\hline
\end{tabular}

\section{Conclusion}

In the present study, the chemical composition for tomatoes and its products were assessed and considered as good sources in lycopene content, antioxidant activities, and Vitamin $\mathrm{C}$ content. Tomato paste was highest in lycopene content . Processing of tomatoes using high temperatures significantly increased the lycopene content after two months of freezer storage. Antioxidant activity increase by storing for one month in the freezer. Vitamin $\mathrm{C}$ percent of tomato paste increased after two months of freezer storage.

\section{References}

Abdulnabi, A. A.; Emhemed, A. H.; Hussein, G. D. and Biacs, P. A. (1997). Determination of antioxidant vitamins in tomatoes. Food Chem $60: 207-212$.

Abou-Aziz, A. B., El-Nataway, S. M., Adel-Wahab, F. K., Kader and A. A. (1976). The effect of storage temperature on quality and decay percentage of 'Pairi' and 'Taimour' mango fruit. Sci. Hortic., 5: 6572.

Agarwal, S. and Rao, A. V. (2000). Tomato lycopene and its role in human health and chronic diseases. Canadian Medical Association Journal,163 (6):739 -744. 
Alda, L. M.; Gogoasa, D.; Bordean, D.M.; Gergen, I.; Alda, S.; Moldovan, C. and. Niţa, L. ( 2016). Lycopene content of tomatoes and tomato products. Journal of Agroalimentary Processes and Technologies, 540-542

A. O. A. C. (1998). Official Methods of Analysis. Association of Official Analytical Chemists. 17th. A. O. A. C., Washington, USA. DC.

A. O. A. C. (2003). Official methods of Analysis of the Association of official's analytical Chemists. 17th ed. Association of Official analytical Chemists. Arlington: Virginia.

Auito, W. R and Bramlage, W. J. (1986). Chilling sensitivity of tomato fruits in relation to ripening and senescence. J. Amer. Soc. Hort. Sci., 111(2): 201-205.

Bernhardt, S. and Schlich, E. (2006). Impact of different cooking methods on food quality: Retention of lipophilic vitamins in fresh and frozen vegetables Journal of Food Engineering, 77:327-333.

Brown, E.; Micozzi, M.; Craft, N.; Bieri, J.; Beecher, G. and Edwards, B. (1989). Plasma carotenoids in normal men after a single ingestion of vegetables or purified beta-carotene. Am J Clin Nutr., 49:1258-65.

Borguini, R. G. and Torres, E. A. F. D.(2009). Tomatoes and tomato products as dietary sources of antioxidants. Food Reviews International, 25:313-325.

Capanoglu, E.; Beekwilder, J.; Boyacioglu, D.; Hall, R. D. and De Vos, C, H. R. (2008). Changes in antioxidant and metabolite profiles during production of tomato paste. Journal of Agriculture and Food Chemistry, 56(3): 964-973.

Capanoglu, E.; Beekwilder, J.; Boyacioglu, D.; DENOS R, C. H. and Hall R.(2010). The Effect of Industrial Food processing on potential health-Beneficial tomato antioxidants. Critical Reviews in Food Science and Nutrition, 50:919-930.

Chitarra, M. I. F. (1994). Colheita e pós-colheita de frutos. Informe Agropecuário.,:17: 8-18

Ensminger, A. H .; Ensminger, M. E.; K onlande , J. E. ( 1995).The concise encyclopedia of foods and nutrition. CRC Press Bocca Raton. London, Tokyo.

FAOSTAT 2011.FAO Statistics Database. Food and agriculture Organization.

Garangyo, T.; Thiombiano, T.; Werem, A.; Drawara, B.; and Sawadogo, L. (1992). Etude de l'impact du change Solaire direct sure la tenure en vit c de la tomato. Science Technology, 20: 53-61. 
Farneti, B.;Zhang,W .;Witkowska, I. and Woltering, E. J. (2009). Effect of home -refrigerator storage temperature on tomato quality. I SHE international Society for Horticulture Science. www.actahort.org/books/877/877 162.htm.pp 11991-1196.

George, B.; Kaur, C.; Khurdiya, D. S. and Kapoor, H. C. (2004).Antioxidants in tomato (Lycopersium esculentum) as a function of genotype. Food Chem., 84: 45-51.

Hadley, C. W.; Miller, E. C.; Schwartsm, S. J. (2002). Tomatoes, Leycopene and prostate cancer. Progress and Promise. Experimental Biology and Medicine (Maywood), 227:869-880.

Hobson, G. E. (1981). The short-term storage of tomato fruit. J. Hortic. Sci., 56: 363-368.

Ilahya, R.; Hdiderb, C.; Lenucci.; M.S.; Tlili, I. and Dalessandro, G. (2011). Phytochemical composition and antioxidant activity of highlycopene tomato (Solanum lycopersicum L.) cultivars grown in Southern Italy. Sci Horticulturae, 127: 255-261.

Jamil, Q. (1990). Storage Stability of Tomato Concentrate. M. Sc. Thesis. Dept. Food Technol. Univ. Agric. Faisalabad .

Jonsson, I. (1991). Thermal degradation of carotenoids and inýuence of their physiological functions, in Nutrition and Toxicological Consequences of Food Processing, Ed by Friedman M. Plenum Press, New York, NY, USA, pp 75.82

Leoni, C. and Jongen, W. (2002). Improving the nutritional quality of processed fruits and vegetables: The case of tomatoes. Fruit and vegetable processing: Improving quality:52-66.

Lugasi, A. ; Bíró, L., Hóvárie, J.; Sági, K.V.; Brandt, S. and Barna, E. (2003). Lycopene content of foods and lycopene intake in two groups of the Hungarian population. Nutrition Research, 1.23:10351044.

Lyc-o-mato. (accessed 2003 Aug 26). www. lycored. com / Lyc -o -Mato. com.

Novelina.; Nazir, N. and Adrian, M. R. (2016). The Improvement Lycopene Availability and Antioxidant Activities of Tomato (Lycopersicum esculentum, Mill) Jelly Drink. Agriculture and Agricultural Science Procedia., 328 - 334 
Parnell, T. L., Suslow, T.V. and Harris, H. L.J. (2004). Tomatoes: Safe Methods to Store,Preserve, and Enjoy. UNIVERSITY OF CALIFORNIA, Agriculture and Natural Sources, Communication Services, 6701 San Pablo Avenue, 2nd Floor, Oakland, California 94608-1239.

Petro-Turza, M. (1987). Flavor of tomato and tomato products. Food Rev. Int. 2, (3): 309-351.

Pinela, J.; Barros, L.; Carvalho, A. M. and Ferreira, I. C. F. R. (2012). Nutritional composition and antioxidant activity of four tomato (Lycopersicon esculentum L.) farmer' varieties in Northeastern Portugal homegardens. Food Chemistry and Toxicology, 50, No. (34).,829-834.

Rao, A. and Agarwal, S. (1999). Role of lycopene as antioxidant carotenoid in the prevention of chronic diseases: A review. Nutr Res.,19:30523.

Rao, A. V. and Agarwal, S. (2000) Role of antioxidant lycopene in cancer and heart disease. J Am Coll Nutr;19:563-9.

Sahlin, E.; Savage, G. P. and Lister, C. E.( 2004). Investigation of the antioxidant properties of tomatoes after processing. J Food Composit Anal., 17: 635-647.

Stahl, W. and Sies, H. (1992). Uptake of lycopene and its geometrical isomers is greater from heat-processed than from unprocessed tomato juice in humans. J Nutr., 122:2161-6.

Toor, R. K . and Savage, G. p. (2005) Antioxidant activities in different fractions of tomato. Food Research International, 38:487-494.

USDA. (2009). Food Composition Databases United States Department of Agriculture Agricultural Research Service.

Viskelis, P.; Vilkauskaite, G. and Noreika, R. K. ( 2005) Chemical composition, functional properties and consumption of tomatoes. Sodininkyste ir Darzininkyste; 24(4) 182 -192. 


\section{الملخص العربى}

\section{تأثثر التخزين على المركبات النشطة بيويوجيا في الطماطم ومنتجاتها}

تعتبر الطماطم غذاء وظيفي بسبب محتواها الكبير من الألياف الغذائية ومضادات الأكسدة.

وبناء على ذلك ، أجريت الدراسة الحالية لدراسة تأثير تخزين الطماطم ومنتجاتها (العصير والصلصة ومعجون الطماطم) في الثلاجة لمدة أسبوع وأسبوعين وفى الفريزر لمدة شهر ، شهرين وثلاثة أثهر على المركبات النشطة بيولوجيا ـ اظهرت النتائج زيادة ملحوظة في محتوى الليكوبين للمنتجات لمدة شهرين

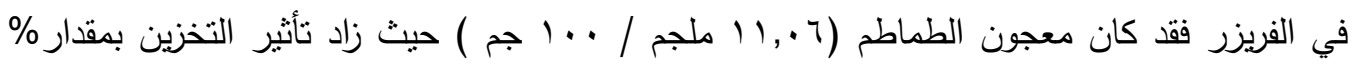

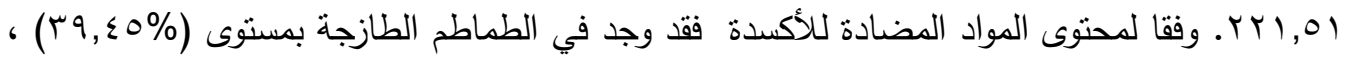

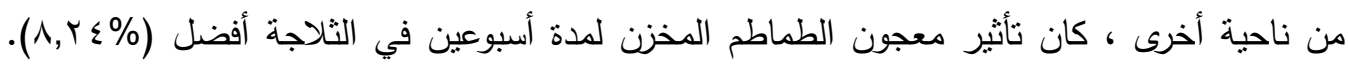
بينما كان التخزين لمدة شهر واحد في الفريزر هو الأفضل (\% (9,07). وايضا كان أعلى محتوى من

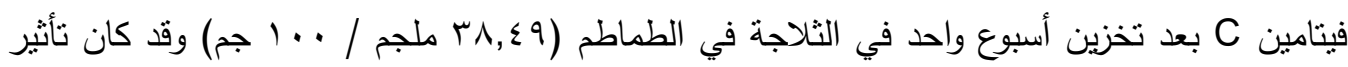
التخزين لمعجون الطماطم ازداد فى محتوى فيتامين C بنسبة \% 1 I,Y, بعد شهرين من تخزينه بالثلاجة. وهكذا كنوصى بعمل معون الطماطم بسبب احتوائه على كمية لا بأس بها من مضادات

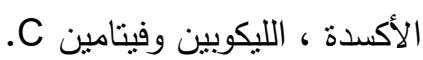

